\title{
PENERAPAN MODEL PEMBELAJARAN KOLABORATIF DENGAN TEKNIK THINK ALOUD PAIR PROBLEM SOLVING PADA MATERI HIDROKARBON SISWA KELAS X SMA NEGERI 6 PALU
}

\author{
Application of Collaborative Learning Model with Think Aloud Pair Problem Solving \\ Technique in the Hydrocarbon Topic in Class X SMAN 6 Palu.
}

\section{*Ekanovi Pratiwi A. Durufin, Sri Mulyani Sabang dan Irwan Said}

Pendidikan Kimia/FKIP - Universitas Tadulako, Palu - Indonesia 94118

Received 5 March 2018, Revised 6 April 2018, Accepted 4 May 2018

\begin{abstract}
This study was conducted to determine differences of the student's learning outcomes that was applied by collaborative learning model with technique think aloud pair problem solving (TAPPS) and was applied by lecture method in the hydrocarbon material against the student's learning outcomes in class X SMAN 6 Palu. The collaborative learning model was think aloud pair problem solving technique on the hydrocarbon material class X SMAN 6 Palu. The type of research was a quasi-experimental with research design pretest posttest control group design. Population in this research was whole students in class X SMAN 6 Palu, academic year 20152016 consisting of six classes totaling 115. The sampling technique used was a purposive sampling. The samples in this research was an experiment class with 17 students and a control class with 8 students. Data analysis techniques used was non-parametric and statistical method of Mann-Whitney U-test. Research result showed the output Rank for mean score of the experiment class was bigger than the control class $22.41>13.83$. The output statistics test, Sig. 2-tailed (0.13) $0.05<$ and $U_{\text {calculation }}(78)<U_{\text {table }}$ (93). From the findings of hypothesis testing, $H_{0}$ was rejected and $H_{a}$ was accepted then it can be concluded that there were significant differences learning outcomes in the student's with the collaborative learning model technique think aloud pair problem solving (TAPPS) with the lecture method on the hydrocarbon material against the learning outcome of students in class X SMAN 6 Palu.
\end{abstract}

Keywords: Collaborative learning, think a loud pair problem solving, hydrocarbons, non-parametric, Mann-Whitney U-test.

\section{Pendahuluan}

Salah satu masalah yang dihadapi dunia pendidikan adalah masalah proses pembelajaran. Proses pembelajaran siswa kurang didorong untuk mengembangkan kemampuan berfikir. Proses pembelajaran di sekolah hanya diarahkan kepada kemampuan anak untuk menghafal informasi, otak anak dipaksa untuk memahami informasi yang diingatnya untuk menghubungkan dengan kehidupan sehari-hari. Akibatnya, ketika anak didik lulus dari sekolah, hanya pintar secara teoritis tetapi miskin aplikasi (Sanjaya, 2006).

Pendidikan adalah suatu proses dalam rangka mempengaruhi peserta didik supaya mampu menyesuaikan diri sebaik mungkin dengan lingkungannya, dapat menimbulkan perubahan dalam dirinya, dan berfungsi dalam kehidupan masyarakat. Pengajaran bertugas mengarahkan proses ini agar sasaran dari perubahan itu dapat tercapai sebagaimana yang diinginkan. Sekolah sebagai suatu lembaga pendidikan formal, secara sistematis merencanakan bermacam-macam

*Correspondence

Ekanovi Pratiwi A. Durufin

Program Studi Pendidikan Kimia, Fakultas Keguruan dan Ilmu Pendidikan, Universitas Tadulako

e-mail: ekanovi_pratiwi@yahoo.co.id

Published by Universitas Tadulako 2018 lingkungan yakni lingkungan pendidikan yang menyediakan berbagai kesempatan bagi peserta didik untuk melakukan berbagai kegiatan belajar. Berbagai kesempatan belajar, pertumbuhan dan perkembangan peserta didik diarahkan dan disusun untuk mencapai tujuan yang dicita-citakan. Lingkungan tersebut disusun dan ditata dalam suatu kurikulum yang pada gilirannya dilaksanakan dalam bentuk proses pembelajaran (Hamalik, 2012).

Kurikulum adalah suatu program pendidikan yang disediakan untuk membelajarkan siswa melakukan berbagai kegiatan belajar. Tujuannya agar terjadi perubahan tingkah laku siswa, sesuai dengan tujuan pendidikan dan pembelajaran (Hamalik, 2012). Sampai saat ini, kurikulum yang diberlakukan di Indonesia salah satunya adalah kurikulum tingkat satuan pendidikan (KTSP). Kurikulum tingkat satuan pendidikan ini telah berjalan selama 6 tahun dan semestinya dilaksanakan secara utuh pada setiap sekolah. Namun kenyataanya, pelaksanaan KTSP dalam proses pembelajaran di sekolah masih kurang memperhatikan ketercapaian kompetensi siswa (Yuditia, 2013).

Proses pembelajaran juga membutuhkan strategi belajar mengajar yang merupakan sarana untuk mencapai tujuan-tujuan belajar. $\mathrm{Hal}$ ini sesuai dengan pernyataan Wijayanti, (2014) bahwa faktor lain yang ikut menentukan keberhasilan 
siswa dalam belajar matematika, salah satu diantaranya adalah metode pembelajaran yang dipilih oleh guru sebagai pengajar.

Salah satu strategi pembelajaran yang dapat melibatkan siswa aktif dalam proses belajar mengajar di sekolah dan mampu meningkatkan hasil belajar serta terampil dalam memecahkan suatu permasalahan adalah pembelajaran dengan menggunakan pembelajaran kolaboratif. Model pembelajaran kolaboratif para pengajar merancang desain kegiatan pembelajaran untuk siswa dan siswa bekerja secara berpasangan atau dalam kelompok kecil untuk mencapai tujuan pembelajaran bersama. Setiap anggota kelompok harus bekerja sama secara aktif untuk meraih tujuan yang telah ditentukan (Barkley dkk., 2014).

Penyelesaian tugas kelompok harus bekerja sama secara aktif untuk meraih tujuan yang telah ditentukan sehingga terjadi proses pembelajaran yang penuh makna. Ketika para siswa bekerja sama dalam sebuah tugas kolaboratif, siswa diharapkan mendapatkan peningkatan pengetahuan. Tugas yang diberikan kepada kelompok harus terstruktur sehingga tujuan pembelajaran dapat tercapai. Pembelajaran kolaboratif adalah perpaduan dua atau lebih siswa yang bekerja bersama-sama dan berbagi beban kerja sehingga secara perlahan dapat mewujudkan hasil-hasil pembelajaran yang diinginkan (Barkley dkk., 2014).

Sekolah yang menerapkan kurikulum KTSP di kota Palu salah satunya adalah SMAN 6 Palu. Mata pelajaran kimia tingkat SMA untuk kelas X semester 2 pada kurikulum 2006, berisi materi hidrokarbon. Pemahaman konsep atom karbon dalam ilmu kimia merupakan dasar yang penting karena gejala yang sering dijumpai dalam kehidupan sehari-hari atau senyawa yang paling banyak ditemukan di alam, baik yang berasal dari senyawa organik, senyawa anorganik, maupun yang dihasilkan secara sintesis di laboratorium atau industri. Membelajarkan materi tersebut diperlukan model pembelajaran yang dapat membuat siswa terlibat aktif dan mengembangkan kemampuan berpikir, siswa dituntut tidak hanya lebih banyak mendengarkan informasi dari guru, tetapi lebih aktif dalam memecahkan masalah bersama. Strategi mengajar yang diusulkan untuk meningkatkan kemampuan pemecahan masalah melibatkan model pembelajaran yaitu menyusun strategi mengajar berpotensi efektif untuk membantu siswa mengembangkan kemampuan pemecahan masalah (Pastel, 1993).

Model pembelajaran yang dapat diterapkan salah satunya dalam kategori penyelesaian masalah yaitu model pembelajaran kolaboratif dengan teknik think aloud pair problem solving (TAPPS). Teknik TAPPS pembelajaran menekankan pada penyelesaian masalah ketimbang hasil, membantu siswa mendiagnosa kesalahan-kesalahan dalam logika. Teknik ini juga dapat membantu meningkatkan kesadaran siswa terhadap cakupan pendekatan keberhasilan dan kegagalan yang mungkin digunakan untuk menyelesaikan masalah, teknik TAPPS dapat meningkatkan keterampilan analitis dengan membantu siswa memformulasi gagasan, melatih konsep, memahami susunan langkah yang mendasari pemikiran dan mengidentifikasi kesalahan dalam penalaran orang lain (Barkley, dkk., 2014).

Tulisan ini mendeskripsikan perbedaan hasil belajar siswa yang diterapkan model pembelajaran kolaboratif dengan teknik think aloud pair problem solving (TAPPS) dan siswa yang diterapkan model pembelajaran ceramah pada materi hidrokarbon terhadap hasil belajar siswa kelas X SMA Negeri 6 Palu.

\section{Metode}

Penelitian ini dilakukan di SMA Negeri 6 Palu Kelurahan Duyu, Kecamatan Tatanga, Kota Palu Provinsi Sulawesi Tengah. Populasi penelitian ini berjumlah 115 orang terdiri dari seluruh kelas X di SMA Negeri 6 Palu yang terdaftar pada tahun ajaran 2015-2016 yang terdiri dari 6 kelas. Teknik pengambilan sampel yang digunakan adalah dengan cara purposive sampling. Teknik sampling ini digunakan untuk menentukan sampel berdasarkan pertimbangan-pertimbangan tertentu, diantaranya lingkungan belajar siswa, siswa diajar oleh guru yang sama, serta harus mewakili populasi berdasarkan ciri-ciri yang telah ditentukan (Margono, 2004). Hasil penentuan sampel di peroleh yaitu kelas XA sebanyak 18 siswa sebagai kelas kontrol dan kelas XF sebanyak 17 siswa sebagai kelas eksperimen.

Desain penelitian yang dilakukan adalah desain penelitian pretest posttest control group design. Pengumpulan data penelitian dilakukan berasal dari penilaian proses yang dilakukan dalam proses belajar, pretest, dan posttest yang telah divalidasi (Sudjana \& Ibrahim, 2012).

Instrumen tes yang berupa 40 soal pilihan ganda divalidasi dengan cara mengujikannya pada kelas XI IPA 1 SMA Negeri 6 Palu sebelum digunakan. Instrumen ini dianalisis dengan aplikasi Anates V4. Hasil pengujian validitas butir soal, daya pembeda, tingkat kesukaran dan reliabilitas tes menggunakan software Anates V4.0.9 (Fuad, 2015).

Analisis data penelitian dilakukan dengan menggunakan metode analisis statistik komparatif dua sampel independen yaitu uji Mann-Whitney. Uji Mann-Whitney adalah uji nonparametrik yang menjadi alternatife dari uji-t (uji parametrik). Uji Mann-Whitney disebut juga sebagai uji U (Sugiyono, 2010).

\section{Hasil dan Pembahasan}

Data penelitian berasal dari nilai pretest dan posttest yang menggunakan tes tertulis berupa soal pilihan ganda yang telah divalidasi sebanyak 20 soal. Pretest dilakukan pada kelas eksperimen dan kelas kontrol untuk mengetahui kemampuan awal siswa pada kedua kelas mengenai materi hidrokarbon. Kemampuan awal siswa adalah aspek kognitif yang dinilai dari jawaban soal. Hasil 
analisis data pretest siswa diperoleh seperti terlihat pada Tabel 1 .

Tabel 1 Hasil analisis data pretest

\begin{tabular}{lcc}
\hline \multirow{1}{*}{ Uraian } & \multicolumn{2}{c}{ Tes Awal (Pretest) } \\
\cline { 2 - 3 } & $\begin{array}{c}\text { Kelas } \\
\text { eksperimen } \\
\left(\mathrm{X}_{1}\right)\end{array}$ & $\begin{array}{c}\text { Kelas } \\
\text { kontrol } \\
\left(\mathrm{X}_{2}\right)\end{array}$ \\
\hline Sampel & 17 & 18 \\
Nilai terendah & 15 & 10 \\
Nilai tertinggi & 75 & 75 \\
Banyaknya siswa yang & 16 siswa & 17 siswa \\
belum tuntas & & \\
Nilai rata-rata & 38,82 & 35,55 \\
Standar deviasi & 19 & 16,61 \\
\hline
\end{tabular}

Berdasarkan hasil pada Tabel 1 menunjukkan bahwa rata-rata nilai pretest hasil belajar siswa kelas eksperimen lebih tinggi dari rata-rata nilai pretest hasil belajar siswa kelas kontrol namun perbedaannya tidak terlalu signifikan. Hal ini berarti bahwa rata-rata nilai pretest hasil belajar siswa kelas eksperimen sama dengan rata-rata nilai pretest hasil belajar siswa kelas kontrol.

Tahap akhir setelah selesai pembelajaran yaitu dilaksanakan posttest pada kelas eksperimen dan kelas kontrol untuk mengetahui hasil belajar siswa pada kedua kelas mengenai materi hidrokarbon yang telah dipelajari. Hasil analisis data posttest siswa diperoleh seperti terlihat pada Tabel 2.

Tabel 2 Hasil analisis data posttest

\begin{tabular}{lcc}
\hline \multirow{1}{*}{\multicolumn{1}{c}{ Uraian }} & \multicolumn{2}{c}{ Tes Akhir (Posttest) } \\
\cline { 2 - 3 } & $\begin{array}{c}\text { Kelas } \\
\text { eksperimen } \\
\left(\mathrm{X}_{1}\right)\end{array}$ & $\begin{array}{c}\text { Kelas } \\
\text { kontrol } \\
\left(\mathrm{X}_{2}\right)\end{array}$ \\
\hline Sampel & 17 & 18 \\
Nilai terendah & 25 & 15 \\
Nilai tertinggi & 80 & 75 \\
Banyaknya siswa yang & 14 siswa & 16 siswa \\
belum tuntas & & \\
Nilai rata-rata & 55 & 32,27 \\
Standar deviasi & 16,95 & 16,79 \\
\hline
\end{tabular}
Tabel 3 Deskripsi hasil analisis data untuk pengujian hipotesis

\begin{tabular}{cccccccc}
\hline Variabel & Kelas & Rerata & $\mathrm{U}_{\text {hitung }}$ & $\begin{array}{c}\mathrm{U}_{\text {tabel }} \\
(0,05 / 2)\end{array}$ & P. Sig & A & Kesimpulan \\
\hline \multirow{2}{*}{ Hasil Belajar } & $\begin{array}{c}\text { Eksperimen } \\
\text { Kontrol }\end{array}$ & $\begin{array}{c}55 \\
32,27\end{array}$ & 78 & 93 & 0,013 & 0,05 & $\mathrm{H}_{\mathrm{a}}$ diterima \\
\hline
\end{tabular}

Berdasarkan data Tabel 2, menunjukkan bahwa rata-rata nilai posttest hasil belajar siswa kelas eksperimen yang sebesar 55 lebih tinggi daripada rata-rata nilai posttest hasil belajar siswa kelas kontrol yang sebesar 32,27. Dengan demikian, terbukti bahwa penerapkan model pembelajaran kolaboratif dengan teknik TAPPS pada kelas eksperimen memberikan hasil belajar yang lebih tinggi dibandingkan kelas kontrol yang diajar melalui metode ceramah.

Pengujian selanjutnya dari data nilai posttest kemudian dianalisis dengan menggunakan uji Mann-Whitney U-test. Pengujian kebenaran hipotesis dilakukan dengan menggunakan uji
Mann-Whitney. Uji nonparametrik digunakan untuk menganalisis data dengan tidak dilandasi persyaratan data harus berdistribusi normal dan sampel dalam penelitian ini berjumlah 18 siswa pada kelas eksperimen dan 17 siswa pada kelas kontrol. Uji statistik juga ditentukan oleh jumlah data yang di analisis, bila jumlah data kecil $(<30)$ cenderung digunakan uji nonparametrik (Riyanto, 2013).

Hasil dari analisis Mann-Whitney U-test memenuhi kriteria pengujian hipotesis $\mathrm{H}_{\mathrm{a}}$ diterima dan $\mathrm{H}_{0}$ ditolak jika, $\mathrm{U}_{\text {hitung }}$ lebih kecil dari $\mathrm{U}_{\text {tabel, }}$ untuk sampel berjumlah maksimal 20 orang. Penelitian ini, sampel berjumlah 21 orang pada kelas eksperimen dan 22 orang pada kelas kontrol, maka pengujian hipotesisnya menggunakan pendekatan tabel Z. Adapun hipotesis yang diajukan dalam penelitian ini adalah ada perbedaan hasil belajar siswa setelah menerapkan model pembelajaran TAPPS pada materi hidrokarbon kelas X SMA Negeri 6 Palu. Hasil analisis pengujian, untuk variabel hasil belajar yaitu $Z_{\text {hitung }}$ $<\mathrm{Z}_{\text {tabel}}$, Asymp.Sig.(2-tail) $<\alpha$. Dengan hasil tersebut maka dapat disimpulkan bahwa hipotesis yang diajukan adalah menolak $\mathrm{H}_{0}$ dan menerima $\mathrm{H}_{2}$, artinya ada perbedaan hasil belajar siswa yang menggunakan model pembelajaran kolaboratif dengan teknik TAPPS terhadap hasil belajar siswa pada materi hidrokarbon pada kelas X SMA Negeri 6 Palu. Deskripsi data untuk pengujian hipotesis disajikan pada Tabel 3.

Perbedaan hasil belajar siswa yang diperoleh karena perbedaan proses pembelajaran yang diterapkan pada kelas kontrol menggunakan metode ceramah dan kelas eksperimen menggunakan model pembelajaran kolaboratif dengan teknik TAPPS. Hal ini sesuai dengan pernyataan Rohman, (2013) bahwa pembelajaran dengan teknik think aloud pair problem solving siswa terlibat aktif untuk bekerjasama dalam kelompok secara berpasangan saling membantu, mendukung dan melengkapi untuk mencari solusi menunjukkan bahwa ada peningkatan yang signifikan pada siswa dalam pemecahan masalah. Meskipun TAPPS tidak membantu dalam meningkatkan pengetahuan konseptual siswa tetapi siswa dapat memiliki pemahaman yang kuat agar dapat menyusun rencana untuk memecahkan masalah. Jeon dkk, (2005) menyatakan bahwa siswa dalam pemecahan masalah dan berinteraksi lisan dengan pasangan berpikir keras menunjukkan bahwa siswa dalam kelompok TAPPS mempunyai pengetahuan konseptual yang lebih baik.

Proses pembelajaran yang menyenangkan, menarik, komunikasi yang terjalin dengan baik
Kani \& Shahrill (2015) dalam penelitiannya 
antara guru dengan siswa dan antar siswa, secara langsung ataupun tidak, membuat siswa merasa nyaman dan senang dalam mengikuti proses pembelajaran di dalam kelas. Komunikasi yang terjalin dengan baik antara guru dengan siswa, misalnya saat siswa mengajukan pertanyaan atau gagasan, guru selalu memberi kesempatan kepada siswa dan menanggapinya dengan baik. Hal ini sesuai dengan pernyataan yang dikemukakan Pate dkk., (2004) bahwa the thinking aloud pair problem solving (TAPPS) technique is a strategy for improving problem solving performance through verbal probing and elaboration.

Hasil yang diperoleh menunjukkan bahwa model TAPPS merupakan strategi untuk meningkatkan kemampuan penyelesaian masalah melalui penyelidikan dan perluasan verbal. Hal ini sesuai dengan pernyataan Desriyanti, (2014) yang menjelaskan bahwa kelebihan TAPPS adalah melibatkan siswa untuk mengoreksi penjelasan dari pasangannya. TAPPS bertujuan untuk menghindari jawaban yang sederhana dalam pemecahan masalah dan meningkatkan daya pikir siswa. Hal tersebut sejalan dengan pendapat Wichelt, (2009) menyatakan: "most of my students are interested in just getting the answer without really understanding how they got there in the first place. I want my students to be able to.communicate with their peers and their teachers. If students can communicate their steps and answer questions about how they reached the answer, then they have a good understanding of the topic." Maksudnya bahwa komunikasi dibutuhkan ketika siswa dihadapkan dengan permasalahan atau soal sehingga mereka paham bagaimana tahap-tahap penyelesaiannya.

Selama penelitian berlangsung, ditemukan beberapa kendala diantaranya alokasi waktu yang dirancang selama penelitian terutama dalam diskusi kelompok kurang berjalan efektif sehingga berdampak pada alokasi waktu untuk kegiatan seterusnya. Hal ini telah diperingatkan oleh Johnson \& Chung, (1999) bahwa TAPPS memerlukan banyak waktu. Namun pada kenyataanya waktu pembelajaran sering berkurang dari jadwal. Kendala tersebut diatasi dengan cara memberikan soal mandiri yang direncanakan dikerjakan di sekolah terkadang dijadikan sebagai pekerjaan rumah (PR) bagi siswa. Kegiatan yang kurang optimal dalam kegiatan pembelajaran ini adalah penggunaan buku pelajaran yang masih kurang, siswa hanya memiliki LKS pada proses pembelajaran, sehingga siswa kesulitan dalam membuat soal. Solusinya yaitu dengan mencari reverensi buku yang lain diperpustakaan atau menggunakan internet dengan fasilitas wifi sekolah.

\section{Kesimpulan}

Berdasarkan hasil penelitian dan analisa data, diperoleh hasil belajar siswa output Rank untuk nilai mean kelas eksperimen lebih besar dari kelas kontrol yaitu $22,41>13,83$. Output test statistics, Sig. 2-tailed $(0,013)<0,05$ dan $U_{\text {hitung }}(78)<U_{\text {tabel }}$
(93). Hal ini menyatakan bahwa nilai posttest kelas eksperimen menggunakan model pembelajaran kolaboratif dengan teknik think aloud pair problem solving lebih baik daripada kelas kontrol menggunakan model pembelajaran ceramah. Dari hasil pengujian hipotesis yang dilakukan, maka $\mathrm{H}_{0}$ ditolak dan $\mathrm{H}_{\mathrm{a}}$ diterima sehingga dapat disimpulkan bahwa terdapat perbedaan yang signifikan pada hasil belajar siswa yang diterapkan model pembelajaran kolaboratif dengan teknik think aloud pair problem solving (TAPPS) dan siswa yang diterapkan motode ceramah pada materi hidrokarbon terhadap hasil belajar siswa kelas X SMAN 6 Palu.

\section{Ucapan Terima Kasih}

Penulis mengucapkan terima kasih kepada kepala sekolah SMA Negeri 6 Palu, guru kimia di SMA Negeri 6 Palu, siswa-siswa SMA Negeri 6 Palu serta semua pihak yang telah membantu penulis dalam penyelesaian penelitian ini.

\section{Referensi}

Barkley, E. E., Cross, K. P., \& Major, C. H. (2014). Collaborative learning techniques. Bandung: Nusa Media.

Desriyanti, Y. (2014). Pengaruh metode pembelajaran thinking aloud pair problem solving (tapps) terhadap kemampuan penalaran adaptif matematik siswa. Jakarta: Universitas Islam Negeri Syarif Hidayatullah.

Fuad, M. F. (2015). Perbedaan hasil belajar biologi siswa dengan menggunakan Model pembelajaran problem based learning dan project based learning pada konsep fungi. Jakarta: Universitas Islam Negeri Syarif Hidayatullah.

Hamalik, O. (2012). Kurikulum dan pembelajaran. Jakarta: Bumi Aksara.

Jeon, K., Huffman, D., \& Noh, T. (2005). The effects of thinking aloud pair problem solving on high school students' chemistry problemsolving performance and verbal interactions. Journal of Chemical Education, 82(10), 15581564.

Johnson, S. D., \& Chung, S, P. (1999). The effect of thinking aloud pair problem solving on the troubleshooting ability of aviation technician students. Journal of Industrial Teacher Education, 37(1), 7-25.

Kani, N, H, A., \& Shahrill, M. (2015). Applying the thinking aloud pair problem solving strategy in mathematics lessons. Asian Journal of Management Sciences \& Education, 4(2), 2028.

Margono. (2004). Metodologi penelitian pendidikan. Jakarta: Rineka Cipta.

Pate, M, L. Wardlow, G, W., \& Johnson, D, M. (2004). Effects of thinking aloud pair problem solving on the troubleshooting performance of undergraduate agriculture students in a power 
technology course. Journal of Agricultural Education, 45(4), 1-11.

Pastel, B, C. (1993). Teaching problem solving without modeling through thinking aloud pair problem solving. Science Education, 77(1), 8394.

Riyanto, A. (2013). Statistik inferensial. Yogyakarta: Nuha Medika.

Rohman, M. G. (2013). Keefektifan model pembelajaran tapps terhadap kemampuan pemecahan masalah matematika kelas $x$ materi ruang dimensi tiga di man 2 kudus. Semarang: Universitas Negeri Semarang.

Sanjaya. (2006). Strategi pembelajaran berorientasi standar proses pendidikan Jakarta: Kencana.

Sudjana, N., \& Ibrahim. (2012). Penelitian dan penilaian pendidikan. Bandung: Sinar Baru Algensindo.
Sugiyono. (2010). Statistik nonparametrik. Bandung: Alfabeta.

Wichelt, L. (2009). Communication: A vital skill of mathematics Action Research Projects Paper is. Lincoin. University of Nebraska.

Wijayanti, I. (2014). Pengaruh metode pembelajaran TAPPS (thinking aloud pair problem solving) terhadap prestasi belajar matematika siswa kelas viii $\mathrm{mts}$ negeri jetis tahun ajaran 2013-2014. Surabaya: Universitas Muhammadiyah Ponorogo

Yuditia, P. R. (2013). Studi komparasi metode pembelajaran the learning cell dengan metode pembelajaran artikulasi terhadap hasil belajar teknologi informasi dan komunikasi (TIK). Kumpulan Artikel Siswa Pendidikan Teknik Informatika, 2(6), 790-795. 